\section{Chondrodysplasia punctata and maternal systemic lupus erythematosus}

\author{
Helga V Toriello
}

In this issue, Elçioglu and Hall ${ }^{1}$ and AustinWard et $a l^{2}$ have both described infants with chondrodysplasia punctata (CP) and maternal systemic lupus erythematosus (SLE). Elçioglu and Hall ${ }^{1}$ further point out that Costa et $a^{\beta}$ and Mansour et $a l^{4}$ had also described infants with CP and maternal SLE, so the occurrence of these two conditions becomes highly unlikely to be coincidental, but rather causal in some fashion, with maternal SLE somehow involved in the occurrence of CP in the exposed infant.

It must first be reiterated that $C P$ is a finding, not a diagnosis, and as such can have numerous causes, which are well reviewed by Wulfsberg et $a \bar{P}$ and Poznanski. ${ }^{6}$ Vitamin $\mathrm{K}$ involvement is the common thread in the pathogenesis of several conditions with $\mathrm{CP}$, with these conditions including warfarin embryopathy, vitamin $\mathrm{K}$ epoxide reductase deficiency, and maternal malabsorption leading to vitamin $\mathrm{K}$ deficiency ${ }^{7}$; however, it is almost certainly not the only mechanism whereby CP can develop. Although Howe et al had postulated a role for abnormal vitamin $K$ metabolism in phenytoin teratogenesis (in which CP can also occur), more recently Danielsson et al have suggested embryonic hypoxia/ischaemia secondary to embryonic bradycardia induced by phenytoin as the pathway which causes phenytoin teratogenesis. Franco et $a l^{10}$ described mutations in arylsulphatase $\mathrm{E}$ in patients with $\mathrm{X}$ linked recesssive CP, and in the same issue of Nature Genetics, Purdue et $a l^{11}$ assert that deficiency of the human homologue of the yeast PEX7 gene causes rhizomelic CP, whereas Chang et $a l^{12}$ describe human homologue of PEX12 mutations in peroxisome biogenesis disorders, which include several entities with CP (see also editorial by Subramani ${ }^{13}$ ). The mechanism whereby these abnormal gene products produce $C P$, as well as the other phenotypic manifestations of the condition, is not yet well understood. Another condition associated with CP is Conradi-Hunermann syndrome, which is thought to be caused by a lipid metabolic defect ${ }^{14}$; this is intriguing in light of the finding of CP in some children with Smith-LemliOpitz syndrome, which is caused by a defect in 7-dehydrocholesterol metabolism. In yet other conditions in which CP can occur (for example, trisomies 18 and 21 , fetal alcohol or rubella syndrome), no pathogenetic pathway has been found. It is therefore an understatement that there are numerous ways in which $\mathrm{CP}$ can be induced to occur in the fetus, and thus it should not be surprising that maternal SLE is yet another cause of CP in the exposed infant.

But how does SLE cause, or contribute to, the occurrence of CP? It is known that patients with SLE are prone to develop hypoprothrombinaemia secondary to lupus anticoagulant and acquired factor II deficiency ${ }^{15}$; this is intriguing in that at one time haemorrhage was thought to be the mechanism which caused CP. Other antibodies, such as IgG anticardiolipin and anti- $\mathrm{B}_{2}$-glycoprotein I, have been implicated in the development of thrombosis in SLE patients. ${ }^{16}$ Furthermore, there is an association of platelet autoantibodies with major histocompatibility complex class II alleles, ${ }^{17}$ suggesting genetic differences for the likelihood of developing thrombosis or thrombocytopenia as a complication of SLE. This is pertinent in that there are almost certainly genetic factors which must be present in order for the CP to occur; this is shown by both the apparent rarity of the occurrence of CP in children born to women with SLE, and yet the occurrence in sibs as described by Elçioglu and Hall. ${ }^{1}$ However, before we can fully understand the pathogenesis involved, it is important to determine the frequency of CP in children whose mothers have SLE during pregnancy, whether there are any common denominators (such as certain antibody profiles) in women whose children are affected, and how these factors could affect bone and cartilage development. In turn, this research could lead to a better understanding of how CP is caused by other prenatal exposures or genetic syndromes, thus giving us insights into the various pathogenetic mechanisms.

1 Elçioglu N, Hall CM. Maternal systemic lupus erythematosus and chondrodysplasia punctata in two sibs: phenocopy or and chondrodysplasia punctat f Med Genet 1998;35:690-4.

2 Austin-Ward E, Castillo S, Cuchacovich M, et al. Neonatal Austin-Ward E, Castillo $S$, Cuchacovich $M$, et al. Neonatal
lupus syndrome: a case with chondrodysplasia punctata lupus syndrome: a case with chondrodysplasia punctata
and other unusual manifestations. $\mathcal{F}$ Med Genet 1998;35: and other

3 Costa T, Tiller G, Chitayat D, Silverman E. Maternal systemic lupus erythematosis (SLE) and chondrodysplasia punctata in two infants. Coincidence or association? 1st Meeting of Bone Dysplasia Society, Chicago, fune 1993. 
4 Mansour S, Liberman D, Young I. Brachytelephalangic chondrodysplasia punctata in an extremely premature chondrodysplasia punctata in an extr
infant. Am $\mathcal{F}$ Med Genet 1994;53:81-2.

5 Wulfsberg EA, Curtis J, Jayne CH. Chondrodysplasia punctata: a boy with $\mathrm{X}$-linked recessive chondrodysplasia punctata due to an inherited X-Y translocation with a current classification of these disorders. Am $\mathcal{F}$ Med Genet 1992 43:823-8.

6 Poznanski AK. Punctate epiphyses: a radiologic sign not a disease. Pediatr Radiol 1994;24:418-24.

7 Menger H, Lin AE, Toriello HV, et al. Vitamin K deficiency embryopathy: a phenocopy of the warfarin embryopathy due to a disorder of embryonic vitamin $\mathrm{K}$ metabolism. $A m$ $\mathcal{f}$ Med Genet 1997;72:129-34.

8 Howe AM, Lipson AH, Sheffield LJ, et al. Prenatal exposure to phenytoin, facial development, and a possible role for vitamin K. Am ₹ Med Genet 1995;58:238-44.

9 Danielsson BR, Azarbayjani F, Skold AC, Webster WS. Initiation of phenytoin teratogenesis: pharmacologically induced embryonic bradycardia and arrhythmia resulting in hypoxia and possible free radical damage at reoxygenation. Teratology 1997;56:271-81.

10 Franco B, Meroni G, Parenti G, et al. A cluster of sulfatase genes on Xp22.3: mutations in chondrodysplasia punctata (CDPX) and implications for warfarin embryopathy. Cell 1995;81:15-25
11 Purdue PE, Zhang JW, Skoneczny M, Lazarow PB. Rhizomelic chondrodysplasia punctata is caused by deficiency of human PEX7, a homologue of the yeast PTS2 receptor. Nat Genet 1997;15:381-4.

12 Chang CC, Lee WH, Moser H, Valle D, Gould SJ. Isolation of the human PEX12 gene, mutated in group 3 of the peroxisome biogenesis disorders. Nat Genet 1997;15:385-8.

13 Subramani S. PEX genes on the rise. Nat Genet 1997;15: 331-2.

14 Emami S, Hanley KP, Esterly NB, Daniallinia N, Williams ML. X-linked dominant ichthyosis with peroxisomal deficiency. Arch Dermatol 1994;130:325-36.

15 Williams $\mathrm{S}$, Linardic $\mathrm{C}$, Wilson $\mathrm{O}$, et al. Acquired hypoprothrombinemia: effects of Danazol treatment. $A m \mathcal{F}$ Hematol 1996;53:272-6.

16 Swadzba J, De Clerck LS, Stevens WJ, et al. Anticardiolipin, anti- $\mathrm{B}_{2}$-glycoprotein $\mathrm{I}$, antiprothrombin antibodies, and lupus anticoagulant in patients with systemic lupus erythematosus with a history of thrombosis. 7 Rheumatol 1997;24:1710-15.

17 Panzer S, Pabinger I, Gschwandtner ME, et al. Lupus anticoagulants: strong association with the major histocompatibility complex class II and platelet antibodies. $\mathrm{Br} \mathcal{F}$ Haematol 1997;98:342-5. 